3 Berger R, Berhein A, Sasportes M, et al. Regional mapping of the HLA on the short arm of chromosome 6. Clin Genet 1979;15:245-51.

4 Breuning MH, Bijlsma JB, de France HF. Partial trisomy $6 \mathrm{p}$ due to familial translocation $\mathrm{t}(6 ; 20)(\mathrm{p} 21 ; \mathrm{p} 13)$. A new syndrome? Hum Genet 1977;38:7-13.

5 Arakaki DT, Sparkes RS. Microtechnique for culturing leucocytes from whole blood. Cytogenetics 1963;2:57-60.

6 Seabright M. A rapid banding technique for human chromosomes. Lancet 1971 ;ii:971-2.

7 Caspersson T, Zech L, Johansson C, Modest EJ. Identification of human chromosomes by DNA-binding fluorescent agents. Chromosoma 1970;30:215-7.

8 Boyum A. Separation of leukocytes from blood and bone marrow. Scand J Clin Lab Invest 1968;21 suppl 97.

9 Mittal K, Mickey MR, Singal DP, Terasaki PI. Serotyping for homotransplantation XVIII. Refinement of microdroplet lymphocyte cytotoxicity test. Transplantation 1969;6:904.

10 Gutierrez C, Bernabé R, Vega J, Kreisler M. Purification of human $T$ and $B$ cells by a discontinuous density gradient of Percoll. J Immunol Methods 1979;29:57-63.

11 Alper CA, Bokisch T, Watson L. Genetic polymorphism in human glycine-rich beta-glicoprotein. J Exp Med 1972;135:68-80.

12 Parr CW, Bagster IA, Welch SG. Human red cell glyoxalase I polymorphism. Biochem Genet 1977;15: 109-13.

13 Bernhein A, Berger R, Vaugier G, Thieffry JC, Matet Y. Partial trisomy 6p. Hum Genet 1979;48:13-6.

14 Yunis JJ, Ball DW, Sawyer JR. G-banding patterns of high-resolution human chromosomes 6-22, $\mathrm{X}$ and $\mathrm{Y}$. Hum Genet 1979;49:291-306.

15 Festenstein H, Demant P. HLA and H2. London: Arnold, 1978:52.

16 Histocompatibility Testing. Copenhagen: Munksgaard, 1977:35-115, 279-91.

17 Bodmer WF. A new genetic model for allelism and histocompatibility and other complex loci: polymorphism for control of gene expression. Transplant Proc 1973; $5: 1471-5$.

18 Garrido F, Festenstein H, Schrrimancher V. Further evidence for depression of $\mathbf{H}-2$ and Ia-like specificities of foreign haplotypes in mouse tumor cell lines. Nature $1976 ; 261: 705$.

Requests for reprints to Dr P Ferrando, Servicio de Genética Médica, C E Ramón y Cajal, Madrid 34, Spain.

\section{An infant with ring 17 chromosome and unusual dermatoglyphs: a new syndrome?*}

SUMMARY A case of ring 17 chromosome in a 5-month-old male infant is investigated and compared with five previously reported cases. The findings commonly observed in these patients include mental and motor retardation,

*Supported in part by Medical Service Grant C-261 March of Dimes Birth Defects Foundation.

Received for publication 20 June 1980 seizures, short stature, muscular hypotonia, and microcephaly among others. Dermatoglyphic studies showed an increased number of ulnar loops. More interestingly, bilateral transverse hypothenar creases were noted. Two of the reported cases also had unspecified genital abnormalities. The variation in clinical findings among these patients may be explained by a difference in the breakpoints on chromosome 17.

To the best of our knowledge this is the third report of a liveborn child with ring 17 chromosome without mosaicism confirmed by banding. We present here the clinical findings in our patient compared to those observed in other cases with and without mosaicism as described in published reports.

\section{Case report}

The proband (fig 1) was the first child of nonconsanguineous parents born after an uncomplicated 42 week pregnancy. The birthweight was $1290 \mathrm{~g}$. The mother was 32 and the father was 34 years old.

The patient was seen at 5 months of age with a weight of $4432 \mathrm{~g}$, head circumference $36.6 \mathrm{~cm}$, and length $53.3 \mathrm{~cm}$ (all below the 3rd centile). Inner canthal distance was $30 \mathrm{~mm}$ and outer canthal distance was $76 \mathrm{~mm}$ (below the 97th centile). Anterior fontanelle size was $5.5 \mathrm{~cm}$ (greater than the 97th centile). The forehead was flattened and he had unruly hair. The nasal bridge was broad and depressed with anteverted nostrils. The palpebral fissures had a downward slant with epicanthal folds. $\mathrm{He}$ had a disconjugate gaze and an alternating esotropia. The ears were low set, with the left ear being larger than the right. Flattening of the helix,

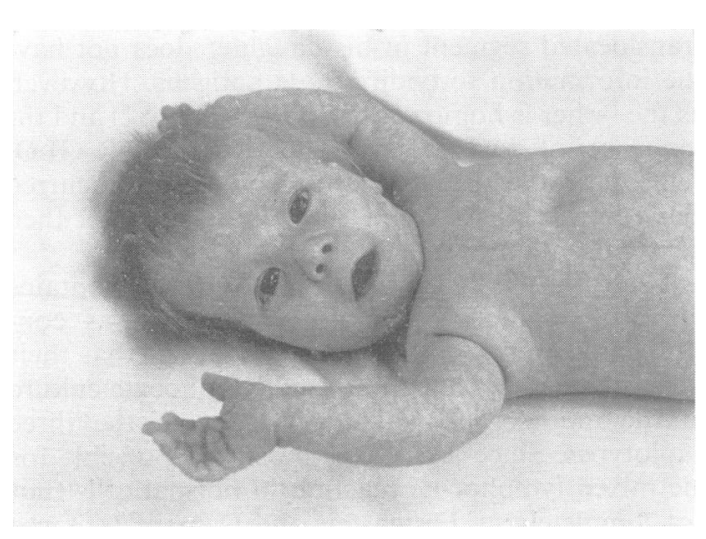

FIG 1 Proband at 5 months of age. 
antihelix, and tragus was noted on the left. Both upper and lower lips appeared thin. Testes were palpable in the scrotum and the urinary meatus was normally placed. There was fifth finger clinodactyly bilaterally.

Dermatoglyphic analysis showed ten ulnar loops on the finger tips and $t^{\prime \prime}$ triradii located in the hypothenar areas of both palms. There was considerable ridge dotting and some dissociation. Transverse hypothenar creases were also noted bilaterally (fig 2).

At $2 \frac{1}{2}$ months of age, the patient was admitted to hospital with gastroenteritis. Five days after admission he had two grand mal seizures. The electroencephalogram was normal, but computerised tomography of the brain showed hydrocephalus involving the anterior portion, occipital, and temporal horns of both lateral ventricles. He was started on phenobarbital and has had no subsequent seizures. Developmental testing at 4 months of age showed a Developmental Quotient of 40 with gross and fine motor ceilings of 6 weeks.
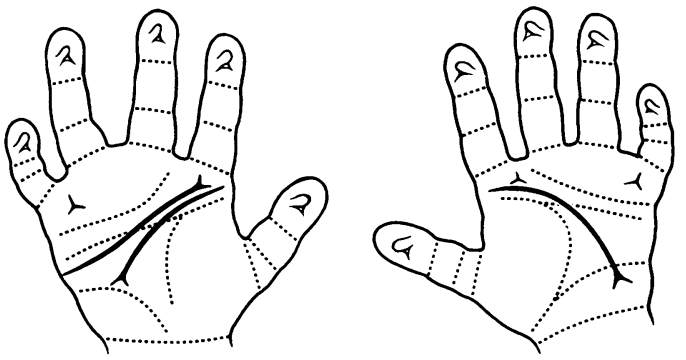

FIG 2 Dermatoglyphic patterns of the proband.
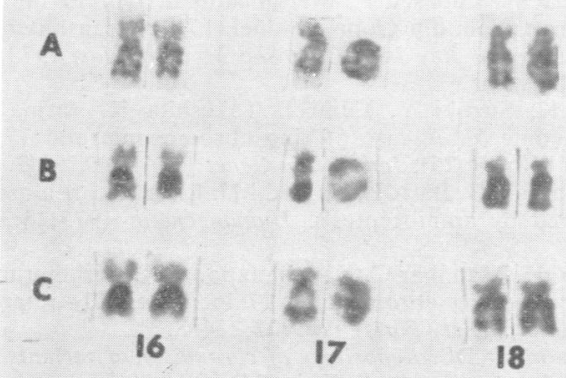

FIG 3 E group chromosomes of the proband from fibroblast $(A)$ and peripheral lymphocyte ( $B$ and $C$ ) cultures.

\section{CYTOGENETIC STUDIES}

Chromosomal analysis of 30 peripheral lymphocyte and 50 skin fibroblast metaphases by $\mathrm{G}$ banding, using a modification of Seabright's technique, ${ }^{1}$ showed a 46,XY,r(17) karyotype with breakpoints located at p13 and q25 (fig 3). The karyotypes of the parents were normal, except that the mother had an enlarged satellite on one chromosome 14, which was not seen in the child.

\section{Discussion}

This is the sixth report of a patient with ring 17 chromosome and the third such case without mosaicism (to be confirmed by banding studies) in a liveborn infant. The patient had mental retardation, short stature, low weight, hypotonia, microcephaly, seizures, hydrocephalus, and abnormal dermatoglyphs.

Petit and Koulischer ${ }^{2}$ reported a child with the mosaic karyotype $46, X X / 46, X X, r(17)$, confirmed by autoradiography, who had mental retardation, short stature, and low birthweight. A father and son were described by Burdea et $\mathrm{al}^{3}$ to have the karyotype $46, X Y, r(17)$, which was not, however, confirmed by banding. The father was reported to have moderate microcephaly, while the son had mental retardation and minor phenotypic abnormalities. Ono et $a l^{4}$ described a 10 -year-old girl with a $46, \mathrm{XX}, \mathrm{r}(17)(\mathrm{p} 13 ; \mathrm{q} 25)$ karyotype who had short stature, microcephaly, mental retardation, hypotonia, and seizures. At the age of 12 , her seizures became uncontrollable with subsequent mental deterioration (Nakagome, 1980, personal communication). In the fourth report by Weinberg et al $^{5}$ banding studies indicated a 46,XX,r(17) karyotype in amniotic fluid cells. A necropsy after a therapeutic abortion at 20 weeks' gestation showed no abnormalities either grossly or microscopically. However, it was recorded that subtle abnormalities of facial development might not be apparent at this stage. Qazi et $a l^{6}$ reported a mentally retarded 6-year-old boy with speech delay, seizures, abnormal facial features, and abnormal dermatoglyphs. Another case of a mosaic $46, \mathrm{XX} / 46, \mathrm{XX}, \mathrm{r}(17)$ is listed in Borgaonkar et $\mathrm{al}^{7}$ but no clinical information is available.

A comparison of our findings with those reported in previous cases of ring 17 chromosome, both with and without mosaicism, are shown in the table. On the basis of the common findings in the present case and previously reported cases, with the exception of the father in Burdea et al, ${ }^{3}$ a pattern emerges suggesting a recognisable syndrome associated with this (chromosome abnormality. The non-specific findings present in the majority of the cases were: 
TABLE Clinical findings in reported cases of $r(17)$ chromosome with and without mosaicism

\begin{tabular}{|c|c|c|c|c|c|}
\hline & Present case & Qazi et al6 & Ono et al 4 & Burdea et $a l^{3}$ & $\begin{array}{l}\text { Petit and } \\
\text { Koulischer }{ }^{2} \text { (mosaic) }\end{array}$ \\
\hline $\begin{array}{l}\text { General findings } \\
\text { Mental and motor retardation } \\
\text { Seizures } \\
\text { Short stature and underweight } \\
\text { Muscular hypotonia } \\
\text { Café-au-lait spots }\end{array}$ & $\begin{array}{l}+ \\
+ \\
+ \\
+ \\
-\end{array}$ & $\begin{array}{l}+ \\
+ \\
- \\
+\end{array}$ & $\begin{array}{l}+ \\
+ \\
+ \\
+ \\
+\end{array}$ & $\begin{array}{l}+ \\
0 \\
- \\
+ \\
0\end{array}$ & $\begin{array}{l}+ \\
0 \\
+ \\
-\end{array}$ \\
\hline $\begin{array}{l}\text { Craniofacial findings } \\
\text { Microcephaly } \\
\text { Slanted forehead } \\
\text { Depressed nasal bridge } \\
\text { Anteverted nostrils } \\
\text { Malformed ears } \\
\text { Epicanthus } \\
\text { Ocular hypertelorism } \\
\text { Funduscopic abnormalities } \\
\text { Strabismus }\end{array}$ & $\begin{array}{l}+ \\
+ \\
+ \\
+ \\
+ \\
+ \\
+ \\
+\end{array}$ & $\begin{array}{l}- \\
- \\
+ \\
+ \\
+ \\
+ \\
\overline{0}\end{array}$ & $\begin{array}{l}+ \\
+ \\
+ \\
+ \\
- \\
- \\
+ \\
0\end{array}$ & $\begin{array}{l}+ \\
\\
0 \\
0 \\
0 \\
+ \\
+ \\
0 \\
0\end{array}$ & $\begin{array}{l}0 \\
-+ \\
+ \\
+ \\
0 \\
- \\
- \\
0\end{array}$ \\
\hline $\begin{array}{l}\text { Dermatoglyphic findings } \\
\text { Transverse hypothenar creases } \\
\text { Many ulnar loops }\end{array}$ & $\begin{array}{l}+ \\
+\end{array}$ & $\begin{array}{l}+ \\
+\end{array}$ & $\overline{+}$ & $\begin{array}{l}0 \\
0\end{array}$ & $\begin{array}{l}- \\
-\end{array}$ \\
\hline $\begin{array}{l}\text { Other findings } \\
\text { Genital abnormalities } \\
\text { Clinodactyly of 5th fingers }\end{array}$ & $\bar{t}$ & $\bar{t}$ & $\begin{array}{l}+ \\
+\end{array}$ & $\stackrel{+}{0}$ & $\overline{0}$ \\
\hline
\end{tabular}

mental and motor retardation, growth retardation, microcephaly, flattened nasal bridge and anteverted nostrils, epicanthus, clinodactyly, and hypotonia. Seizures and café-au-lait spots, not commonly seen in other chromosomal syndromes, were present in the majority of patients. Most interestingly, the dermatoglyphic findings show the presence of a transverse hypothenar crease in the present case. This crease has previously been described only in Coffin-Lowry syndrome (Plato, 1980), personal communication. Only two illustrations of dermatoglyphic patterns of the hands were available in the reported cases and, of these, one case reported by Qazi et ${ }^{6}{ }^{6}$ also had transverse hypothenar creases.

With the limitations of the present banding techniques, it is not always easy to determine the breakpoints which result in a ring chromosome. Certainly a difference in the breakpoints, and thus the area involved in the terminal deletions, could account for differences in phenotypes. However, the size of the ring chromosomes and the location of the breakpoints appear to be quite similar in our case and those of Weinberg et $a l_{,}^{5}$ Ono et al, ${ }^{4}$ and Qazi et al. ${ }^{6}$

More accurately, one way to determine the extent of the deletion of this chromosome would be through the use of biochemical markers. Karyotype-phenotype correlations will be difficult to achieve until more individual gene products can be studied.

The authors wish to thank Gaurang Munshi, Paul Fullerton, and Kathryn Jones for their technical assistance, Hoyt Smith for the dermatoglyphic illustration, and Kathy Peaden for editing.

Nancy J Carpenter, Lawrence G Leichtman, SuzanNe Stamper, and Burhan Say Department of Clinical Genetics, Children's Medical Center, PO Box 35648, Tulsa, Oklahoma 74135, USA

\section{References}

1 Seabright M. A rapid banding technique for human chromosomes. Lancet 1971 ;ii:971-2.

2 Petit P, Koulischer L. Etude d'une mosaique 46,XX 46,XX,17r. Ann Genet (Paris) 1971;14:55-8.

3 Burdea M, Lupascu E, Margineanu L. Un caz familial de chromozom din grupa e in inel (17)r cu transmitere de la tata la fiu. Rev Med Chir Soc Med Nat Iasi 1973;77: 353-7.

4 Ono K, Suzuki Y, Fuijii I, Takeshita K, Arima M, Nakagome Y. A case of ring chromosome and 17:46, XX,r(17)(p13q25). Jpn J Hum Genet 1974;19:235-42.

5 Weinberg AG, Bair JL, Harrod MJ. Ring 17 chromosome $\mathrm{N}$ detected by amniocentesis. Humangenetik 1975;28:26972.

6 Qazi QH, Madahar C, Kanchanapoom R, Giridharan R, Beller E. Ring chromosome 17 in a mentally retarded boy. Ann Genet (Paris) 1979;22:234-8.

7 Borgaonkar DS. Repository of chromosomal variants and 0 anomalies in man. Sixth listing. Denton, Texas: Genetics Center and Department of Biological Sciences, 1979.

Requests for reprints to Dr Burhan Say, Department of Clinical Genetics, Children's Medical Center, PO Box 35648, 5300 E Skelly Drive, Tulsa, Oklahoma 74135, USA. 